\title{
TAMPILAN AGRONOMI BEBERAPA VARIETAS UNGGUL KEDELAI (Glycine max L.) DI TANAH ULTISOL KABUPATEN KUANTAN SINGINGI
}

\author{
AGRONOMIC DISPLAYS OF SOME SUPERIOR VARIETIES \\ SOYBEAN (Glycine max L.) IN ULTISOL SOIL \\ SINGINGI KUANTAN DISTRICT
}

\author{
A.Haitami 1), Elfi Indrawanis ${ }^{2)}$, Chairil Ezward ${ }^{3)}$, Wahyudi ${ }^{4}$ \\ ${ }^{1,2,3)}$ Fakultas Pertanian Universitas Islam Kuantan Singing Email \\ haitami1982@gmail.com.ezwardchairil@yahoo.com,Wahyudi.uniks@gmail.com
}

\begin{abstract}
Abstrak:Penelitian di lakukan untuk mengetahui tampilan agronomi pertumbuhan dan produksi beberapa varietas kedelai (Glycine $\max$ L.) di tanah ultisol Kabupaten Kuantan Singingi. Penanaman kedelai pada tanah ultisol merupakan salah satu upaya peningkatan produksi tanaman kedelai pada lahan kering. Luas lahan ultisol di kabupaten Kuantan Singingi yang berpotensi dalam meningkatkan produksi kedelai dan penggunaan benih kedelai varietas unggul. Penelitian dilaksanakan di Kebun BBU Sentajo Kecamatan Sentajo Kabupaten Kuantan Singingi selama 4 bulan. Penelitian menggunakan Rancangan Acak Kelompok Lengkap (RAKL) yang terdiri dari 6 taraf perlakuan dan 3 kelompok, sehingga didapatkan 18 unit satuan percobaan. Enam Tampilan Varietas adalah Derap 1, Anjasmoro, Detap 1, Dering 1, Grobogan dan Dega 1. Hasil penelitian diuji secara statistik dengan menggunakan program SAS versi 9.0. Memberikan pengaruh nyata. Berdasarkan hasil uji lanjut dengan Uji Lanjut Duncan Multiple Range Test (DMRT) pada taraf 5 $\%$, maka pada paremeter persentase tumbuh varietas kedelai, tinggi tanaman umur 14, 28 dan 42 HST, umur muncul bunga, berat 100 biji, dan jumlah polong berpengaruh nyata, sedangkan parameter berat polong dan berat biji tidak berpengaruh nyata.
\end{abstract}

Kata kunci : Tampilan, Kedelai, Varietas, ultisol

Abstract: This study was conducted to determine the agronomic appearance of growth and production of several varieties of soybean (Glycine max L.) in ultisol soil in Kuantan Singingi Regency. Planting soybeans on ultisol soils is an effort to increase soybean production on dry land. Ultisol land area in Kuantan Singingi district which has the potential to increase soybean production and use of superior varieties of soybean seeds. The research was conducted at the Sentajo BBU Garden, Sentajo District, Kuantan Singingi Regency for 4 months. The study used a completely randomized block design (RAKL) which consisted of 6 treatment levels and 3 groups, in order to obtain 18 experimental units. The six displays of varieties were Derap 1, Anjasmoro, Detap 1, Dering 1, Grobogan and Dega 1. The results were statistically tested using the SAS program version 9.0. Make a real impact. Based on the results of further tests with the Duncan Multiple Range Test (DMRT) Advanced Test at the 5\% level, the parameters of the growth percentage of soybean varieties, plant height at age 14, 28 and 42 DAS, age of flower appearance, weight of 100 seeds, and number of pods had a significant effect, whereas the parameters of pod weight and seed weight had no significant effect.

Keywords: Display, Soybean, Varieties, Ultisols 


\section{A. PENDAHULUAN}

Perluasan areal tanam merupakan salah satu cara peningkatan produksi kedelai nasional. Permasalahan kebutuhan nasional kedelai adalah masih rendahnya teknik produksi berupa teknologi serta pengetahuan yang baik tentang budidaya tanaman kedelai, meningkatkan perluasan areal, perbaiki kualitas, lingkungan dan penggunaan varietas unggul.

Seiring berkembangnya industri pangan dan pakan yang semakin meningkat, maka menjadikan kebutuhan permintaan kedelai semakin tinggi. Di satu sisi produksi kedelai dalam negeri cenderung menurun, mengingat permintaan kedelai sangat tinggi. Maka permasalahan sekarang Indonesia masih tergantung dengan kedelai impor. Oleh sebab itu pemanfaatan lahan kering seperti tanah ultisol dan perluasan areal tanam serta penggunaan varietas unggul menjadi salah satu alternatif dalam nmeningkatkan produksi kedelai di Indonesia.

Potensi lahan kering, seperti tanah Ultisol di Kabupaten Kuantan Singingi menjadi salah satu alternatif dalam pengembangan budidaya tanaman kedelai dengan menggunakan varietas unggul. Tanggap varietas kedelai di lahan ultisol sangat berbeda-beda. Terutama varietas berumur panjang biasa nya tanggap positif dibandingkan kedelai varietas genjah. Produksi Kedelai di Provinsi Riau berdasarkan BPS (2015), produksi kedelai pada tahun 2013 sampai 2015 cenderung menurun 2.211 ton sampai 2.145 ton/ha.

Varietas unggul kedelai sudah banyak dilepas oleh pemerintah, namun belum banyak dari verietas tersebut yang di adopsi oleh petani (Rozi dan Heriyanto, 2012. Varietas unggul tersebut memimiliki keragaman, potensi hasil, umur panen, ukuran biji, watrna biji, dan wilayah adaptasi yang berbeda.

\section{B. METODE PENELITIAN}

Penelitian dilakukan di BBU SentajoKecamatan Sentajo Kabupaten Kuantan. Dengan jenis tanah Ultisol dengan $\mathrm{pH}$ tanah berkisar 5,0-5,6, dimulai dari bulan April 2020 sampai dengan Bulan Juli 2020.

Rancangan yang dipergunakan adalah Rancangan Acak Kelompok Lengkap (RAKL) yang terdiri dari enam taraf perlakuan dan tiga ulangan, sehingga terdapat 15 unit satuan percobaan. Pada satu plot percobaan terdapat 18 tanaman dan 12 diantara nya adalah tanaman sampel, maka ada 324 tanaman. Perlakuan yang diberikan adalah berbagai varietas kedelai yang terdiri dari 5 taraf perlakuan yaitu: $\mathrm{A}=$ Varietas Derap 1, $\mathrm{B}=$ Varietas Anjasmoro, $\mathrm{C}=$ Varietas Detap 1, D =Varietas Dering 1, E = Varietas Grobogan, F = Varietas Dega 1.

Tanah diolah menggunakan cangkul, dan diambil sampel tanah awalnya pada kedalaman 0 - $20 \mathrm{~cm}$ untuk analisis tanah awal. kemudian dibuat petak percobaan berukuran $200 \times 100$ $\mathrm{cm}$,dengan jarak antar petak percobaan $0,5 \mathrm{~m}$ serta jarak antar kelompok 1 meter.

Petak percobaan A, B, C, D, E dan F yang telah dipasang label diberikan kapur dolomitik 2 ton/ha atau setara 400 gram per plot percobaan. Kemudian kapur disebar rata diatas permukaan tanah dan diaduk rata dengan cangkul dan dibiarkan selama 1 minggu. Kemudian dilakukan pemberian pupuk kompos KOTAKPLUS pada se mua petak percobaan dengan dosis Kompos 30 ton/ha (Haitami dan Wahyudi, 2018) diberikan dengan cara disebar secara merata dipermukaan tanah lalu dicampur rata dengan tanah menggunakan cangkul, kemudian dibiarkan 1 minggu. Setelah 1 minggu pemberian kompos, tanah siap untuk ditanami. Penyiraman dilakukan sejak awal tanam sampai mencapai masak fisiologi. Penyiraman dilakukan 2 kali sehari, kecuali saat tutun hujan.

Pengendalian gulma dilakukan dengan penyiangan sesuai kebutuhan, sedangkan pengendalian hama dan penyakit dimulai saat tanaman berumur 14 HST dengan Interval dua minggu sekali sampai menjelang panen. 
Parameter pengamatan meliputi :

1. Persentase Tumbuh Kedelai (\%) dilakukan umur 7 HST

2. Tinggi Tanaman (cm) dilakukan pada umur 14, 28, 42 HST.

3. Umur Muncul Berbunga (HST)

4. Jumlah Polong Total Pertanaman (buah)

5. Berat Polong (g)

6. Bobot Biji (g)

7. Bobot 100 Biji (g)

\section{HASIL DAN PEMBAHASAN}

\section{Persentase Tumbuh Kedelai (\%)}

Pertumbuhan awal tanaman kedelai menunjukkan daya tumbuh rata-rata tanaman kedelai berkisar 91,67 \% sampai $100 \%$ pada umur 7 HST. Daya tumbuh dari berbagai tampilan varietas tersebut tergolong tinggi. Varietas Anjasmoro dan Grobogan daya tumbuh benih nya $100 \%$. Hal ini disebabkan Benih kedelai dari varietas yang ditanam umumnya mampu melakukan proses imbibisi setelah biji ditanam pada kondisi tanah yang lembab. Air berimbibisi melalui keseluruhan permukaan biji, termasuk daerah hilum dan mikrofil. Berdasarkan SNI 01-6234.2-2003 daya kecambah benih kedelai memiliki batas minimum sebesar $80 \%$ sehingga dapat dikatakan benih kedelai anjasmoro dan Grobogan yang digunakan dalam penelitian sangat memenuhi standar SNI. Fase pertumbuhan vegetatif kedelai pada saat umur 3 HST mengalami fase perkecambahan $(\mathrm{Ve})$, fase kotiledon $(\mathrm{Vc})$ pada umur $7 \mathrm{HST}$, fase buku ke satu (V1) pada umur $12 \mathrm{HST}$, fase buku kedua (V2) pada umur $18 \mathrm{HST}$, dan pada fase buku ketiga (V3) pada umur 23 HST. Tanaman kedelai mengakhiri fase vegetative (Vn) dan memulai fase generatif 35-42 HST (R1). Fase berbunga penuh (R2) pada kedelai yang dibudidayakan terjadi pada 42-49 HST. Kedelai muklai membentuk polong (R3) hingga pada tahap polong kedelai berkembang penuh (R4) terjadi saat umur kedelai 49-56 HST. Fase polong kedelai mulai berisi (R5) pada umur 56-63 HST. Fase saat polong kedelai berbiji penuh (R6) pada umur 63-70 HST). Fase saat polong kedelai mulai menguning atau matang (R7) hingga polong matang (R8) terjadi ketika tanaman kedelai berumur 70-98 HST. Panen kedelai dilakukan pada umur 77-98 HST.

Tabel 1.

Persentase Tumbuh 7 HST dari Tampilan Agronomi Beberapa Varietas Kedelai

\begin{tabular}{|l|c|}
\hline $\begin{array}{l}\text { Tampilan Agronomi Beberapa } \\
\text { Varietas Kedelai }\end{array}$ & Persentase Tumbuh Kedelai (\%) \\
\hline Derap 1 & $96,67^{\mathrm{ab}}$ \\
\hline Anjasmoro & $100^{\mathrm{a}}$ \\
\hline Detap 1 & $91,67^{\mathrm{b}}$ \\
\hline Dering 1 & $98,33^{\mathrm{a}}$ \\
\hline Grobogan & $100^{\mathrm{a}}$ \\
\hline Dega 1 & $98,33^{\mathrm{a}}$ \\
\hline
\end{tabular}

Keterangan : Nilai rata-rata yang diikuti oleh huruf kecil yang sama, menunjukkan tidak berbeda nyata pada uji DMRT taraf $5 \%$.

\section{Tinggi Tanaman (cm)}

Tinggi tanaman diukur dari pangkal akar pada permukaan sampai titik tumbuh pada umur 14, 28, dan 42 HST. Dari hasil pengamatan Tampilan Agronomi Beberapa Varietas Kedelai tinggi tanamanmulai umur 14, 28 dan 42 HST tidak semua menunjukkan pengaruh nyata dan 
perlakuan yang terbaik adalah Varietas Detap 1 pada tinggi tanaman umur 14 HST dan Varietas Anjasmoro pada tinggi tanaman umur 42 HST.

Berdasarkan hasil analisis sidik ragam Tampilan Agronomi parameter tinggi tanaman kedelai pada umur 14 dan 42 HST dan uji lanjut DMRT taraf $5 \%$ menunjukkan bahwa varietas Detap 1 dan Anjasmoro pada umur 14 dan 28 HST yaitu pada fase pertumbuhan vegetatif dan memasuki Fase generative memberikan pengaruh nyata terhadap tinggi tanaman kedelai. Rata-rata tinggi tanaman kedelai umur 14, 28, 42 HST dapat dilihat pada tabel.2.

Tabel 2.

Tinggi Tanaman dari Tampilan Agronomi Beberapa Varietas Kedelai pada umur 14, 28, 42 HST

\begin{tabular}{|l|c|c|c|}
\hline $\begin{array}{l}\text { Keragaan Varietas } \\
\text { Kedelai }\end{array}$ & 14 HST & 28 HST & 42 HST \\
\hline Derap 1 & $14,23^{\mathrm{a}}$ & 28,33 & $56,64^{\mathrm{bcd}}$ \\
\hline Anjasmoro & $14,79^{\mathrm{a}}$ & 36,99 & $67,25^{\mathrm{a}}$ \\
\hline Detap 1 & $15,82^{\mathrm{a}}$ & 36,67 & $59,33^{\mathrm{bc}}$ \\
\hline Dering 1 & $12,26^{\mathrm{b}}$ & 30,99 & $60,71^{\mathrm{ab}}$ \\
\hline Grobogan & $14,13^{\mathrm{ab}}$ & 32,12 & $53,04^{\mathrm{cd}}$ \\
\hline Dega 1 & $14,39^{\mathrm{a}}$ & 33,96 & $50,00^{\mathrm{d}}$ \\
\hline
\end{tabular}

Keterangan : Nilai rata-rata yang diikuti oleh huruf kecil yang sama, menunjukkan tidak berbeda nyata pada uji DMRT taraf $5 \%$.

Tampilan Agronomi pada parameter tinggi tanaman yang diuji menunjukkan bahwa varietas Detap 1 memiliki tinggi tanaman paling tinggi yaitu pada 14 HST yaitu $15,82 \mathrm{~cm}$, ada selisih tinggi tanaman 3,56 cm dari varietas Dering 1 yang merupakan varietas yang memiliki tinggi tanaman terendah pada umur 14 HST, kemudian Varietas Anjasmoro pada 28 HST adalah 36,67 cm, ada selisih tinggi tanaman 8,66 cm dari varietas Derap 1 yang merupakan varietas yang memiliki tinggi tanaman terendah pada tinggi tanaman umur $17,25 \mathrm{~cm}$ dari varietas Dega 1 yang merupakan varietas yang memiliki tinggi tanaman terendah pada umur 42 HST. Menurut Rukmana dan Yuniarti (1995) tinggi tanaman kedelai berkisar 30-100 cm. Adapun Kriteria tinggi tanaman kedelai berdasarkan UPOV (1998) dapat dikelompokkan beberapa kelas, yaitu sangat pendek $(<15 \mathrm{~cm})$, pendek $(15-50 \mathrm{~cm})$, sedang $(>50-68 \mathrm{~cm})$, tinggi $(>68-86 \mathrm{~cm})$, dan sangat tinggi $(>86 \mathrm{~cm})$.

Berdasarkan hasil uji lanjut DMRT didapat bahwa varietas Detap 1 dan varietas Anjasmoro memiliki tinggi tanaman berbeda nyata pada semua varietas yaitu Derap 1, Detap 1, Dering 1, Grobogan dan Dega 1. Taryoko et al. (1996), menyatakan bahwa faktor lingkungan dapat mempengaruhi pertumbuhan tanaman sampai pemasakan buah.

Menurut Arsyad et al. (2007), tipe tanaman kedelai ideal (plant-ideotipe) yang berdaya hasil tinggi dan dianggap sesuai pada lingkungan yang optimum antara lain memiliki tinggi tanaman berkisar $60-70 \mathrm{~cm}$.

\section{Umur Muncul Berbunga (HST)}

Parameter Umur muncul Berbunga diukur apabila $75 \%$ dari tanaman sudah berbunga. Dari hasil pengamatan Tampilan Agronomi Beberapa Varietas Kedelai umur muncul berbunga menunjukkan berpengaruh nyata dan varietas kedelai yang paling cepat berbunga adalah varietas Dega 1 yaitu dengan rata-rata 28,67 HST. Ada rentang 3, 33 HST dari Varietas Anjasmoro yang memiliki waktu berbunga agak lambat dari varietas lainnya. Hal ini disebabkan karena factor genetic dari varietas tersebut yang merupakan vareitas genjah. 
Berdasarkan hasil analisis sidik ragam umur muncul berbunga kedelai dan uji lanjut DMRT pada taraf $5 \%$ menunjukkan bahwa varietas Dega 1 memberikan pengaruh nyata terhadap umur muncul berbunga tanaman kedelai. Rata-rata umur muncul berbunga tanaman dapat dilihat pada tabel.3.

Tabel 3.

Umur Muncul Berbunga Tanaman Kedelai dari Tampilan Agronomi Beberapa Varietas Kedelai.

\begin{tabular}{|l|c|}
\hline $\begin{array}{l}\text { Tampilan Agronomi Beberapa } \\
\text { Varietas Kedelai }\end{array}$ & Umur Muncul Bunga \\
\hline Derap 1 & $29,00^{\mathrm{bc}}$ \\
\hline Anjasmoro & $32,00^{\mathrm{a}}$ \\
\hline Detap 1 & $30,33^{\mathrm{b}}$ \\
\hline Dering 1 & $32,00^{\mathrm{a}}$ \\
\hline Grobogan & $29,00^{\mathrm{bc}}$ \\
\hline Dega 1 & $28,67^{\mathrm{c}}$ \\
\hline
\end{tabular}

Keterangan : Nilai rata-rata yang diikuti oleh huruf kecil yang sama, menunjukkan tidak berbeda nyata pada uji DMRT taraf $5 \%$.

\section{Jumlah Polong Total Pertanaman (buah)}

Jumlah polong total adalah jumlah polong isi dan jumlah polong hampa. Tampilan Agronomi pada parameter jumlah polong total pertanaman pada beberapa varietas 59,92 sampai 154,08. Jumlah polong total pertanaman tersebut jika dibandingkan dengan deskripsi masing-masing varietas masih rendah dibawah deskripsi. Namun varietas Dering 1 jumlah polong total pertanaman pada deskripsi adalah 64 polong, sedangkan jumlah polong total pada penelitian ini adalah 154,08 . Artinya kurang 0,29 sudah hampir mendekati jumlah polong total pertanaman pada deskripsi.

Berdasarkan hasil analisis sidik ragam karakter jumlah polong total pertanaman tanaman kedelai dan uji lanjut DMRT taraf 5\% menunjukkan bahwa varietas Demas 1 berpengaruh nyata terhadap jumlah polong total pertanaman. Rata-rata jumlah polong total pertanaman kedelai berkisar 25,54 sampai 63,71. Parameter jumlah polong total pertanaman dapat dilihat pada tabel.4.

Tabel 4.

Jumlah Polong Total Tanaman Kedelai dari Tampilan Agronomi Beberapa Varietas Kedelai.

\begin{tabular}{|l|c|}
\hline $\begin{array}{l}\text { Tampilan Agronomi Beberapa Varietas } \\
\text { Kedelai }\end{array}$ & Jumlah Polong Total per Tanaman \\
\hline Derap 1 & $91,33^{\mathrm{bc}}$ \\
\hline Anjasmoro & $113,67^{\mathrm{b}}$ \\
\hline Detap 1 & $105,08^{\mathrm{b}}$ \\
\hline Dering 1 & $154,08^{\mathrm{a}}$ \\
\hline Grobogan & $74,75^{\mathrm{bc}}$ \\
\hline Dega 1 & $59,92^{\mathrm{c}}$ \\
\hline
\end{tabular}

Keterangan : Nilai rata-rata yang diikuti oleh huruf kecil yang sama, menunjukkan tidak berbeda nyata pada uji DMRT taraf $5 \%$.

Penelitian Adie dan Krisnawati (2007), bahwa semakin kecil ukuran biji pada kedelai maka jumlah polong per tanaman (jumlah polong total pertanaman) semakin banyak. Hal ini sesuai dengan varietas Dering 1 mampu beradaptasi dan tumbuh baik setinggi $57 \mathrm{~cm}$ dalam kondisi tercekam kekeringan selam fase reproduktif. Berdasarkan hasil uji lanjut DMRT pada 
taraf $5 \%$ bahwa varietas Dering 1 berbeda nyata pada varietas Anjasmoro, Detap 1, Derap 1, Grobogan dan dega 1 yang memiliki jumlah polong total yang tidak sama dengan varietas lainnya. Maka karakter jumlah polong total per tanaman menjadi tolak ukur pada hasil biji tanaman kedelai. Hal ini sesuai dengan hasil penelitian Adie et al. (2007), menunjukkan bahwa jumlah polong merupakan penentu hasil biji pada semua varietas kedelai uang diuji. Yullianida dan Susanto (2007), menyatakan bahwa semakin banyak polong tiap tanaman berpeluang untuk mendapatkan hasil yang lebih tinggi per tanaman.

\section{Berat Polong (g)}

Tampilan Agronomi pada parameter berat polong pada beberapa varietas kedelai berkisar antara 43,71 gram sampai 53,63, yaitu vareitas Dega 1 dan Grobogan. Varietas Dering 1 berat polong nya lebih tinggi dibandingkan dengan varietyhras yang lain, ada selisih 9,92 gram dari Varietas Dega 1 yang merupakan berat polong terendah dalam penelitian ini.

Berdasarkan hasil analisis sidik ragam tampilan berat beberapa varietas tanaman kedelai tidak menunjukkan berpengaruh nyata terhadap parameter berat polong pertanaman. Hal ini berarti bahwa semua tampilan varietas kedelai hampir sama dengan persentase $81,50 \%$ berat polong pada setiap varietas kedelai. Rata-rata berat polong kedelai berkisar 43,71 gram sampai 53,63 gram. Parameter berat polong varietas tanaman kedelai dapat dilihat pada tabel.5.

Tabel 5.

Berat Polong Total Tanaman Kedelai dari Tampilan Agronomi Beberapa Varietas Kedelai.

\begin{tabular}{|l|c|}
\hline \multicolumn{1}{|c|}{$\begin{array}{c}\text { Tampilan Agronomi Beberapa } \\
\text { Varietas Kedelai }\end{array}$} & Berat Polong \\
\hline Derap 1 & 47,01 \\
\hline Anjasmoro & 47,95 \\
\hline Detap 1 & 49,14 \\
\hline Dering 1 & 51,66 \\
\hline Grobogan & 53,63 \\
\hline Dega 1 & 43,71 \\
\hline
\end{tabular}

Keterangan : Nilai rata-rata yang diikuti oleh huruf kecil yang sama, menunjukkan tidak berbeda nyata pada uji DMRT taraf $5 \%$.

Penelitian Adie dan Krisnawati (2007), bahwa semakin kecil ukuran biji pada kedelai maka jumlah polong per tanaman (jumlah polong total pertanaman) semakin banyak. Hal ini sesuai dengan varietas grobogan mampu beradaptasi dan tumbuh baik dengan berat polong 53,63 gram dalam kondisi tercekam kekeringan selama fase reproduktif.

\section{Bobot Biji (g)}

Bobot biji per tanaman, yaitu bobot adalah jumlah biji per tanaman yang ditimbang bobot bijinya yang telah lepas dari polong. Berdasarkan hasil analisis sidik ragam tampilan agronomi beberapa varietas kedelai terhadap paramater bobot biji pertanaman $(\mathrm{g})$ tidak berpengaruh nyata. Pada penelitian menunjukkan bahwa varietas Dering 1 merupakan varietas yang memiliki bobot biji tertinggi disbanding dnegan varietas lainnya. Rata-rata bobot biji pertanaman kedelai berkisar antara 22,38 gram yaitu varietas Dega 1 sampai 29,90 gram yaitu varietas Dering 1, dengan rentang berat biji 7,52 gram. Parameter bobot biji pertanaman dapat dilihat pada tabel.6. 
Tabel 6.

Bobot Biji Tanaman Kedelai dari Tampilan Agronomi Beberapa Varietas Kedelai.

\begin{tabular}{|l|c|}
\hline Tampilan Agronomi Beberapa Varietas Kedelai & Bobot Biji (g) \\
\hline Derap 1 & 26,05 \\
\hline Anjasmoro & 27,52 \\
\hline Detap 1 & 28,74 \\
\hline Dering 1 & 29,90 \\
\hline Grobogan & 29,35 \\
\hline Dega 1 & 22,38 \\
\hline
\end{tabular}

Keterangan : Nilai rata-rata yang diikuti oleh huruf kecil yang sama, menunjukkan tidak berbeda nyata pada uji DMRT taraf $5 \%$.

Menurut hasil penelitian Wirnas et al. (2006) bahwa bobot biji pertanaman bisa dipengaruhi langsung oleh karakter jumlah cabang, jumlah polong isi dan persentase polong isi. Hal ini menunjukkan bahwa terdapat perbedaan karakter bobot biji pertanaman dari beberapa varietas yang diuji. Bobot biji pertanaman pada beberapa varietas kedelai ini berkisar antara 10,37 gram sampai 14,05 gram. Ukuran biji kedelai dibagi menjadi 3 kriteria, yaitu besar $(>14$ $\mathrm{g} / 100$ biji), sedang (10 g/100 biji), dan kecil (<10 g/ $100 \mathrm{bji})$ (UPOV, 1998). Menurut Adisarwanto (2010) bahwa kriteria ukuran biji yang ideal untuk kedelai yaitu lebih dari $14 \mathrm{~g}$ per 100 biji. Berdasarkan pengelompokan tersebut, maka beberapa varietas kedelai yang diuji ini termasuk karakter biji berat dan sedang.Kenaikan bobot biji disebabkan faktor genetik dari varietas kedelai. Setiap varietas kedelai memiliki keunggulan genetis yang berbeda-beda sehingga setiap varietas memiliki produksi yang berbeda-beda pula, tergantung kepada sifat varietas tanaman itu sendiri (Soegito dan Arifin, 2004 dalam Jusniati, 2013).

\section{Bobot 100 Biji (g)}

Bobot 100 biji, yaitu bobot 100 butir benih kedelai kering panen. Berdasarkan hasil analisis sidik ragam karakter bobot 100 biji tanaman kedelai dan uji lanjut DMRT taraf 5\% menunjukkan bahwa varietas Grobogan dengan bobot 100 biji 21,76 gram berpengaruh nyata terhadap parameter bobot 100 biji. Rata-rata bobot 100 biji kedelai berkisar antara 11,50 gram sampai 21,76 gram. Parameter bobot100 biji dapat dilihat pada tabel.7.

Tabel 7.

Bobot 100 Biji Tanaman Kedelai dari Tampilan Agronomi Beberapa Varietas Kedelai.)

\begin{tabular}{|l|c|}
\hline \multicolumn{1}{|c|}{$\begin{array}{c}\text { Tampilan Agronomi Beberapa } \\
\text { Varietas Kedelai }\end{array}$} & Bobot 100 Biji (g) \\
\hline Derap 1 & $16,91^{\mathrm{bc}}$ \\
\hline Anjasmoro & $13,97^{\mathrm{cd}}$ \\
\hline Detap 1 & $16,03^{\mathrm{bcd}}$ \\
\hline Dering 1 & $11,50^{\mathrm{d}}$ \\
\hline Grobogan & $21,76^{\mathrm{a}}$ \\
\hline Dega 1 & $19,98^{\mathrm{ab}}$ \\
\hline
\end{tabular}

Keterangan : Nilai rata-rata yang diikuti oleh huruf kecil yang sama, menunjukkan tidak berbeda nyata pada uji DMRT taraf $5 \%$.

Hasil uji lanjut DMRT menunjukkan bahwa Tampilan agronomi berat 100 butir dari enam varietas kedelai memiliki bobot 100 butir biji yang berbeda dengan varietas yang lainnya. Varietas Grobogan tidak berbeda nyata dengan varietas Dega 1, Detap 1, Derap 1, Anjasmoro, dan Dering 1. Interval Bobot 100 butir antara varietas Grobogan yang tertinggi dengan varietas Dering 1 yang merupakan bobot 100 butir yang terendah yaitu 10,26 gram. Hal ini sejalan dengan pendapat Adie dan Krisnawati (2007) menyatakan bahwa biji kedelai dikelompokkan berdasarkan besar (berat $>14 \mathrm{~g} / 100$ biji), sedang (10-14 g/100 biji), dan kecil (<10 g/100/biji). 
Berdasarkan pengelompokan tersebut, maka beberapa varietas kedelai yang diuji ini termasuk karakter biji berat dan sedang.

Hal ini sesuai dengan pendapat. Soegito dan Arifin, (2004) dalam Jusniati, (2013). Mengatakan bahwa setiap varietas memiliki keunggulan genetis yang berbeda-beda sehingga setiap varietas memiliki produksi yang berbeda-beda pula, tergantung kepada sifat varietas tanaman itu sendiri. Dikaitkan dengan perolehan hasil biji, genotipe-genotipe yang berbiji besar tersebut ternyata memiliki hasil bijinya yang juga lebih tinggi (Hakim, 2010). Setiap varietas memiliki keunggulan genetis yang berbeda-beda sehingga setiap varietas memiliki produksi yang berbeda-beda pula, tergantung kepada sifat varietas tanaman itu sendiri.

\section{PENUTUP}

Berdasarkan hasil penelitian yang telah dilakukan maka dapat disimpulkan bahwa berdasarkan uji lanjut dengan Uji Lanjut Duncan Multiple Range Test (DMRT) pada taraf 5 \%, maka pada parameter persentase tumbuh varietas Anjasmoro dan Grobogan berpengaruh nyata, parameter tinggi tanaman varietas Detap 1 dan Anjasmoro berpengaruh nyata, parameter umur muncul berbunga varetas Dega 1 berpengaruh nyata, parameter jumlah polong total varietas Dering 1 berpengaruh nyata, serta parameter bobot 100 butir pada varietas Grobogan berpengaruh nyata.

\section{E. DAFTAR PUSTAKA}

Arsyad, D.M., H.Kuswantoro, dan Purwantoro. 2007. Kesesuaian varietas kedelai di lahan kering masam Sumatera Selatan. Jurnal Penelitian Pertanian Tanaman Pangan 26 (1): 26-31.

Adisarwanto T. 2010. Strategi peningkatan produksi kedelai sebagai upaya untuk memenuhi kebutuhan di dalam negeri dan mengurangi impor. J. Inovasi Pertanian. 3(4):319-331.

Adie, M. dan Krisnawati, A. 2007. Biologi Tanaman Kedelai. Balai Penelitian Kacangkacangan dan Umbi-umbian (BALITKABI). Malang

Badan Pusat Statistik (BPS). 2015. Produksi dan Produktivitas Tanaman Kedelai di Provinsi Riau. http://www.bps.go.id [20 Desember 2020].

Haitami A, Wahyudi. 2018.Pemanfaatan Kompos Tandan Kosong Kelapa Sawit Plus (KOTAKPLUS) terhadap Produksi Kedelai (Glycine max L.) pada Tanah Ultisol. Unri Conference Series: Agriculture and Food Security. Volume 1. 220-225

Hakim, L. 2010. Komponen Hasil dan Karakter Morfologi Penentu Hasil Kedelai. Pusat Penelitian dan Pengembangan TanamanPangan. Bogor.

Rozi dan Heriyanto, 2012. Efektivitas Difusi Teknologi Varietas Kedelai di Tingkat Petani. Buletin Palawija. 24: 49-48.

Wirnas D., Widodo I., Sobir, Trikoesoemaningtyas, dan Sopandi D. 2006. Pemilihan karakter agronomi untuk menyusun indeks seleksi pada 11 populasi kedelai generasi F6. Bul. Agron. 34:19-24.

Yullianida dan G.W.A. Susanto. 2007. Karakteristik shasil galur-galur kedelai umur genjah, hlm 77-87. Dalam: Suharsono, A.K. Makarim, A.A. Rah-mianna, M.M. Adie, A. Taufiq, F. Rozi, I.K. Tastra,dan D. Harnowo (Eds.). Peningkatan Produksi Kacang-kacangan dan Umbi-umbian Mendukung Kemandirian Penelitian dan Pengembangan Per-tanian. Bogor. 